\title{
THE AGROECOLOGICAL IMPACT OF DIFFERENT SOWING DATES AND ROW SPACING APPLICATIONS IN QUINOA (CHENOPODIUM QUINOA WILLD.)
}

\author{
ZULKADIR, G. \\ Mersin University, Applied Technology and Management School of Silifke, Organic Farming \\ Management Department, Silifke, Mersin, Turkey \\ (e-mail: gulayzulkadir@gmail.com) \\ (Received 21 $1^{\text {st }}$ Oct 2020; accepted $18^{\text {th }}$ Dec 2020)
}

\begin{abstract}
Similar to all plants, the region of cultivation and sowing date of the quinoa (Chenopodium quinoa Willd.) plant leads to variations in phenological periods, affecting grain yield (GY) and quality. The present study aimed to determine the adequate sowing date and row spacing for Q-52 quinoa variety, which is known to be suitable for Mediterranean climate conditions, in Kahramanmaraş province. For this purpose, three different row spacing distances (Namely, 20, 40 and $60 \mathrm{~cm}$ ) were adopted with four sowing dates at 15-day intervals between March 15 and May. The study findings demonstrated that the plant emergence period was 5.0-21.0 DAS, the budding period was 19.0-38.0 DAS, the 50\% of flowering period was found as 44.7-67.3 DAS, the grain-filling period (GF) was fixed as 3.2-31.0 DAS, the growth period was realized as 88.0-131.7 DAS, the GY was calculated as 9.8-323.9 $\mathrm{kg} \mathrm{da}^{-1}$, and biological yield (BY) was determined as 70.8-528.5 kg da${ }^{-1}$. Considering the effects of the temperatures on the growth and development of plants, it was concluded that it would be adequate to sow the crops during early or late April. The analysis of the ideal row spacing demonstrated that the highest grain and plant yield was obtained at $20 \mathrm{~cm}$ spacing.
\end{abstract}

Keywords: biological yield, climatic stress, grain yield, phenology, plant density

\section{Introduction}

Quinoa (Chenopodium quinoa Willd.) is a plant belonging to the Amaranthaceae / Chenopodiaceae family. Although it is known that quinoa has been cultured for 5000 years and is indigenous to South America, the cultivation of the plant is common globally (Mujica and Jacobsen, 2006). Quinoa is highly resistant to adverse environmental and climatic factors (Jacobsen, 2003) such as drought, salinity, poor soil, and frost and could be grown from the sea level up to an altitude of $4000 \mathrm{~m}$ (Jacobsen, 2003), between $-8 \mathrm{C}^{\mathrm{o}}$ and $38 \mathrm{C}^{\mathrm{o}}$ ambient temperatures (Zurita-Silva et al., 2014).

The cultivation ecology of the plant directly affects the plant growth and development and determines the volume and quality of the harvest. In other words, although genotypes exhibit differences under different environmental conditions, the differences in total growth period also lead to differences in product quality. To harvest high yield and quality products in quinoa cultivation, it is very important to determine the most adequate cultivation period where the plant could reach technical and physiological maturity by selecting the most adequate variety for the vegetation period (Geren et al., 2014). Although generally low temperature, high relative humidity, and short-term sunlight exposure have negative effects on plants, this is a little different for quinoa. Quinoa is a facultative short-day plant (Tan and Temel, 2017) that should be sowed at the end of winter when the soil temperature is $8^{\circ} \mathrm{C}$ and when it would not experience frost after sowing (Geren et al., 2014). Although the optimum growth temperature is generally $8-35^{\circ} \mathrm{C}$, higher than $28^{\circ} \mathrm{C}$ temperatures during the $50 \%$ of flowering period significantly affect the grain yield (Etchevers and Avila, 1979). Especially during transition to 
generative period and $50 \%$ of flowering periods, the plant is significantly affected during the photoperiod that lasts more than 12 hours (Christiansen et al., 2010).

To maximize yield and quality in quinoa cultivation, ensuring plant requirements that are consistent with environmental conditions during the development period could be achieved by the identification of the most adequate sowing period.

The present study aimed to determine the differences between phenological and yield properties of the quinoa plant by identifying the differences that could be observed in the total growth period with different sowing dates and different row spacing in Mediterranean climate conditions.

\section{Material and methods}

\section{The location and varieties}

The trials were conducted for 2 years in 2017 at Kahramanmaraş Eastern Mediterranean Transitional Zone of Agricultural Research Station (37 $32^{\prime} 17.05^{\prime \prime}$ and $36^{\circ}$ 55' 05.58") and in 2018 at Kahramanmaraş Sütçü İmam University Faculty of Agriculture, Department of Field Crops' Experimental Fields (37 $37^{\circ}$ 8.3436" and $36^{\circ} 49^{\prime} 26.7600$ ). The area where the study was conducted is a region where the typical Mediterranean climate is experienced, summers are hot and dry, winters are warm and rainy. In the study, the quinoa (Chenopodium quinoa Willd.) variety "Q-52", which is well adapted to Mediterranean climate conditions, was used as the plant material.

\section{Applications and experimental design}

The study area was deep-plowed in early winter, and was prepared for sawing in March with plowing second-class tillage equipment. The study was designed with a random blocks trial pattern with 3 replications. Four sowing dates (Namely, 23 March, 6 April, 20 April, 11 May in 2017 and 26 March, 2 April, 13 April, 26 April in 2018) were determined for the trial. The plants were sowed with $20 \mathrm{~cm}, 40 \mathrm{~cm}$ and $60 \mathrm{~cm}$ (4 rows per lot) row spacing on the lines marked with a hand marker and at $1-2 \mathrm{~cm}$ depth. The size of the plots was $4 \mathrm{~m}^{2}, 8 \mathrm{~m}^{2}$ and $12 \mathrm{~m}^{2}$. The amount of seed used on the test plots was $1.8 \mathrm{~kg} \mathrm{da}^{-1}$ for $20 \mathrm{~cm}$ row space, $1.2 \mathrm{~kg} \mathrm{da}^{-1}$ for $40 \mathrm{~cm}$ row space and $0.6 \mathrm{~kg} \mathrm{da}^{-1}$ for $60 \mathrm{~cm}$ row space.

Based on the soil nutrient content (Table 1), the soil was fertilized with $6 \mathrm{~kg} \mathrm{da}^{-1} \mathrm{~N}$, $6 \mathrm{~kg} \mathrm{da}^{-1} \mathrm{P}$ and $6 \mathrm{~kg} \mathrm{da}^{-1} \mathrm{~K}$ as basic fertilizer before sowing. Then, when the plants were about $20 \mathrm{~cm}$, net $7 \mathrm{~kg}^{-1} \mathrm{~N}$ was applied as the second fertilization. Based on the climate conditions, the soil was irrigated based on the water requirement of the quinoa plant (Table 2).

Table 1. Some physical and chemical soil characteristics of experimental areas in the 20172018

\begin{tabular}{c|cc|cc}
\hline \multirow{2}{*}{ Soil properties } & \multicolumn{2}{|c|}{$\mathbf{2 0 1 7}$} & \multicolumn{2}{c}{$\mathbf{2 0 1 8}$} \\
\cline { 2 - 5 } & Values & Comments & Values & Comments \\
\hline Saturation (Saturation with Water) (\%) & 58.00 & Clay-Loamy & 79.00 & Clay \\
pH & 7.76 & Light Alkaline & 7.40 & Neutral \\
EC dS m ${ }^{-1}$ & 0.32 & Light Saline & 0.11 & Saltless \\
Lime (\%) $_{\text {Organic Matter }(\%)}^{24.48}$ & More Lime & 23.00 & Limy \\
Useful Phosphorus $\left(\mathbf{P}_{\mathbf{2}} \mathbf{O}_{\mathbf{5}}\right) \mathbf{~ k g ~ d a ~ d a ~}^{-1}$ & 2.28 & Middle & 2.09 & Middle \\
Useful Potassium $\left(\mathbf{K}_{\mathbf{2}} \mathbf{O}\right) \mathbf{~ k g ~ d a ~}^{-1}$ & 3.20 & Low & 5.62 & Poor \\
\hline
\end{tabular}


Table 2. Some meteorological parameters of experimental areas at Kahramanmaras in 2017 and 2018

\begin{tabular}{c|cc|cc|cc|cc|cc}
\hline \multirow{2}{*}{ Months } & \multicolumn{2}{|c|}{$\begin{array}{c}\text { Max. Temperature } \\
\left({ }^{\circ} \mathbf{C}\right)\end{array}$} & \multicolumn{2}{|c|}{$\begin{array}{c}\text { Min. Temperature } \\
\left({ }^{\circ} \mathbf{C}\right)\end{array}$} & \multicolumn{2}{c|}{$\begin{array}{c}\text { Average } \\
\text { temperature }\left({ }^{\circ} \mathbf{C}\right)\end{array}$} & $\begin{array}{c}\text { Total rainfall } \\
(\mathbf{m m})\end{array}$ & \multicolumn{2}{c}{$\begin{array}{c}\text { Average } \\
\text { moisture }(\boldsymbol{\%})\end{array}$} \\
\cline { 2 - 11 } & $\mathbf{2 0 1 7}$ & $\mathbf{2 0 1 8}$ & $\mathbf{2 0 1 7}$ & $\mathbf{2 0 1 8}$ & $\mathbf{2 0 1 7}$ & $\mathbf{2 0 1 8}$ & $\mathbf{2 0 1 7}$ & $\mathbf{2 0 1 8}$ & $\mathbf{2 0 1 7}$ & $\mathbf{2 0 1 8}$ \\
\hline March & 17.9 & 19.7 & 7.2 & 9.6 & 12.2 & 14.2 & 74.2 & 47.4 & 55.1 & 60.8 \\
April & 21.8 & 25.5 & 10.1 & 12 & 15.7 & 18.4 & 68.1 & 71.6 & 49.7 & 45.3 \\
May & 26.2 & 28.8 & 14.2 & 15.7 & 19.6 & 21.7 & 105.0 & 28.1 & 54.9 & 52.6 \\
June & 33.3 & 32.5 & 19.9 & 19.9 & 26.2 & 25.4 & 3.1 & 39.4 & 43.3 & 49.1 \\
July & 39.1 & 35.6 & 23.9 & 23.2 & 30.9 & 28.6 & 0.0 & 0.3 & 34.9 & 46.2 \\
August & 37.9 & 36.8 & 23.7 & 23.3 & 29.8 & 29.1 & 0.0 & 0.0 & 46.2 & 43.8 \\
September & 36.4 & 34.7 & 21.1 & 21.0 & 27.7 & 27.2 & 0.0 & 0.6 & 38.3 & 38.4 \\
\hline $\begin{array}{c}\text { Total } \\
\text { (Season) }\end{array}$ & 212.6 & 213.6 & 120.1 & 124.7 & 162.1 & 164.6 & 176.2 & 140.0 & 322.4 & 336.2 \\
\hline $\begin{array}{c}\text { Average } \\
\text { (Season) }\end{array}$ & 30.4 & 30.5 & 17.2 & 17.8 & 23.2 & 23.5 & 29.4 & 23.3 & 46.1 & 48.0 \\
\hline
\end{tabular}

The analysis of the soil properties at the study areas where the two-year research was conducted revealed that the soil content at the test sites was low in phosphorus, adequate in potassium and moderate in organic matter. However, based on the year and location, soil saturation was determined as clayey-loamy and clayey, respectively, and the soil was slightly alkaline-neutral, slightly saline/non-saline, highly calcareous-calcareous (Table 1).

Certain climate data for the 2017-2018 cultivation year on the study area are presented in Table 2 (Anonim, 2019). As seen in Table 2, during the trial period, total and average precipitation amount was 176.2 and $29.4 \mathrm{~mm}$ for the first year, 140.0 and $23.3 \mathrm{~mm}$ for the second year. The average temperature was $23.2^{\circ} \mathrm{C}$ during the 2017 cultivation period, the average temperature was $23.5^{\circ} \mathrm{C}$ in the 2018 cultivation period. The mean relative humidity in Kahramanmaraş was $46.1 \%$ and $48.0 \%$ during the cultivation periods in 2017 and 2018, respectively.

\section{Application}

In the study, plant emergence period (PE, DAS), transition to generative period (TG, DAS), $50 \%$ of flowering period (FP, DAS), grain filling period (GF, DAS), growing period (GP, DAS), grain yield (GY, $\mathrm{kg} \mathrm{da}^{-1}$ ) by harvested the whole plots and biological yield (aboveground biomass) by harvested the whole plots (BY, $\mathrm{kg} \mathrm{da}^{-1}$ ) parameters were analyzed.

\section{Statistical analyses}

After obtaining data on the parameters studied, missing data values for the second year were statistically calculated. Analysis of variance was conducted with PROC GLM in SAS v.9.3 with randomized block trial data pattern. Averages were grouped with Duncan's multiple. 


\section{Results and discussion}

In the study, the effects of various sowing date and row spacing applications on the phenological stages, GY and plant yield properties of the quinoa plant were investigated. The year, sowing date, row spacing application and interactions between these parameters are presented in Table 3a,b,c.

Table 3a. Effect of different sowing dates and different row spacings on the phenological characteristics of quinoa in 2017 and 2018

\begin{tabular}{c|c|c|c|c|c|c|c}
\hline & PE (DAS) & TG (DAS) & FP (DAS) & GF (DAS) & G (DAS) & $\begin{array}{c}\text { GY } \\
\left(\mathbf{k g ~ d a}^{-1}\right)\end{array}$ & $\begin{array}{c}\text { BY } \\
\left(\mathbf{k g ~ d a}^{-1}\right)\end{array}$ \\
\hline Years & $* *$ & $* *$ & $* *$ & $* *$ & $* *$ & $* *$ & $* *$ \\
2017 & $12.316 \mathrm{~A}$ & $32.506 \mathrm{~A}$ & $61.000 \mathrm{~A}$ & $26.250 \mathrm{~A}$ & $113.501 \mathrm{~A}$ & $207.128 \mathrm{~A}$ & $351.430 \mathrm{~A}$ \\
2018 & $8.760 \mathrm{~B}$ & $26.993 \mathrm{~B}$ & $54.583 \mathrm{~B}$ & $16.699 \mathrm{~B}$ & $92.276 \mathrm{~B}$ & $79.487 \mathrm{~B}$ & $331.484 \mathrm{~B}$ \\
\hline Sowing Date & $* *$ & $* *$ & $* *$ & $* *$ & $* *$ & $* *$ & $* *$ \\
23/26 March (I) & $13.020 \mathrm{~A}$ & $35.537 \mathrm{~A}$ & $56.667 \mathrm{C}$ & $22.667 \mathrm{~B}$ & $97.103 \mathrm{C}$ & $164.092 \mathrm{C}$ & $379.758 \mathrm{~A}$ \\
06/02 April (II) & $8.532 \mathrm{~B}$ & $29.509 \mathrm{C}$ & $51.722 \mathrm{D}$ & $26.722 \mathrm{~A}$ & $96.594 \mathrm{C}$ & $178.486 \mathrm{~B}$ & $343.036 \mathrm{~B}$ \\
20/13 April (III) & $7.536 \mathrm{C}$ & $30.452 \mathrm{~B}$ & $58.833 \mathrm{~B}$ & $20.111 \mathrm{C}$ & $103.162 \mathrm{~B}$ & $184.901 \mathrm{~A}$ & $371.394 \mathrm{~A}$ \\
04 May/26 April (IV) & $13.065 \mathrm{~A}$ & $23.501 \mathrm{D}$ & $63.944 \mathrm{~A}$ & $16.399 \mathrm{D}$ & $114.694 \mathrm{~A}$ & $45.751 \mathrm{D}$ & $271.640 \mathrm{C}$ \\
\hline Row Spacing (cm) & NS & NS & NS & $* *$ & $* *$ & $* *$ & $* *$ \\
$20 \mathrm{~cm}$ & 10.534 & 29.768 & 57.625 & $21.667 \mathrm{~A}$ & $102.477 \mathrm{~B}$ & $221.655 \mathrm{~A}$ & $401.596 \mathrm{~A}$ \\
$40 \mathrm{~cm}$ & 10.543 & 29.766 & 57.750 & $20.982 \mathrm{~B}$ & $103.474 \mathrm{~A}$ & $138.491 \mathrm{~B}$ & $369.886 \mathrm{~B}$ \\
$60 \mathrm{~cm}$ & 10.538 & 29.715 & 58.000 & $21.775 \mathrm{~A}$ & $102.715 \mathrm{~B}$ & $69.776 \mathrm{C}$ & $252.888 \mathrm{C}$ \\
\hline
\end{tabular}

**: p>0.001; NS: Not significant; PE: Plant emergence period; TG: Transition to generative period; FP: $50 \%$ of flowering period; GF: Grain filling period; GP: Growth period; GY: Grain yield; BY: Biological yield

\section{Plant emergence period (DAS)}

It was determined that the difference between the annual time periods between the sowing and emergence of the quinoa plants on the soil was statistically significant ( $p<0.001)$. It was determined that the emergence period in the second year (8.760 DAS) was shorter when compared to the first year (12.316 DAS). The analysis of the sowing dates demonstrated that there were significant differences between PEs $(\mathrm{p}<0.001)$ and the emergence period for the $3^{\text {rd }}$ sowing date (7.536 DAS) was shorter when compared to the other sowing dates, and it was quite long for the $1^{\text {st }}\left(13.020\right.$ DAS) and $4^{\text {th }}$ sowing dates (13.065 DAS). It was determined that the differences in row distances did not affect the emergence period.

It was determined that there were statistically significant differences $(p<0.01)$ between relative year $\mathrm{x}$ sowing date interactions. The in detail analysis of the year $\mathrm{x}$ sowing date interaction demonstrated that the earliest emergence was in the $3^{\text {rd }}$ sowing in 2017 with 6.053 DAS and in the $1^{\text {st }}$ sowing in 2018 with 5.010 DAS. On the other hand, the latest emergence was observed in $1^{\text {st }}$ sowing in the first year $\left(21.030\right.$ DAS), and in the $4^{\text {th }}$ sowing (13.021 DAS) in the second year.

The analysis of the sowing dates demonstrated that the longer emergence period observed in March was due to the later germination of the plants induced by maximum and minimum temperatures although the average temperature was over $10^{\circ} \mathrm{C}$. On the other hand, although the temperatures were not low in May, problems were experienced with the emergence period and seedling development. This could be explained by both decreasing rainfall and increasing weed growth in this period (Hirich et al., 2014). 
Table 3b. Effect of different sowing dates and different row spacings on the phenological characteristics of quinoa in 2017 and 2018

\begin{tabular}{|c|c|c|c|c|c|c|c|c|}
\hline \multicolumn{2}{|c|}{ INTERACTIONS } & $\begin{array}{c}\text { PE } \\
(\text { DAS })\end{array}$ & $\begin{array}{c}\text { TG } \\
(\text { DAS })\end{array}$ & $\begin{array}{c}\text { FP } \\
(\text { DAS })\end{array}$ & $\begin{array}{c}\text { GF } \\
(\text { DAS) }\end{array}$ & $\begin{array}{c}\text { G } \\
(\text { DAS })\end{array}$ & $\begin{array}{c}\text { GY } \\
\left(\mathrm{kg} \mathrm{da}^{-1}\right)\end{array}$ & $\begin{array}{c}\text { BY } \\
\left(\mathrm{kg} \mathrm{da}^{-1}\right)\end{array}$ \\
\hline \multicolumn{2}{|c|}{ Year X Sowing Date } & $* *$ & $* *$ & $* *$ & $* *$ & $* *$ & $* *$ & $* *$ \\
\hline \multirow{4}{*}{2017} & I & 21.030 & 38.004 & 64.000 & 20.000 & 99.189 & 235.911 & 450.847 \\
\hline & II & 9.072 & 32.010 & 58.000 & 26.000 & 105.111 & 269.194 & 394.799 \\
\hline & III & 6.053 & 32.010 & 60.000 & 31.000 & 118.323 & 283.616 & 467.593 \\
\hline & IV & 13.109 & 28.000 & 62.000 & 28.000 & 131.381 & 39.790 & 92.480 \\
\hline \multirow{4}{*}{2018} & $\mathrm{I}$ & 5.010 & 33.069 & 49.333 & 25.333 & 95.018 & 92.272 & 308.668 \\
\hline & II & 7.992 & 27.008 & 45.444 & 27.444 & 88.078 & 87.778 & 291.273 \\
\hline & III & 9.018 & 28.893 & 57.667 & 9.222 & 88.000 & 86.187 & 275.194 \\
\hline & IV & 13.021 & 19.002 & 65.889 & 4.796 & 98.008 & 51.711 & 450.800 \\
\hline \multicolumn{2}{|c|}{ Year X Row Spacing } & NS & NS & NS & $* *$ & $* *$ & $* *$ & $* *$ \\
\hline \multirow{3}{*}{2017} & $20 \mathrm{~cm}$ & 12.319 & 32.506 & 61.000 & 26.250 & 112.677 & 323.880 & 327.838 \\
\hline & $40 \mathrm{~cm}$ & 12.302 & 32.507 & 61.000 & 26.250 & 114.681 & 204.559 & 443.033 \\
\hline & $60 \mathrm{~cm}$ & 12.328 & 32.506 & 61.000 & 26.250 & 113.146 & 92.944 & 283.418 \\
\hline \multirow{3}{*}{2018} & $20 \mathrm{~cm}$ & 8.748 & 27.031 & 54.250 & 17.083 & 92.277 & 119.431 & 475.354 \\
\hline & $40 \mathrm{~cm}$ & 8.783 & 27.025 & 54.500 & 15.713 & 92.268 & 72.423 & 296.739 \\
\hline & $60 \mathrm{~cm}$ & 8.749 & 26.923 & 55.000 & 17.300 & 92.283 & 46.608 & 222.359 \\
\hline \multicolumn{2}{|c|}{$\begin{array}{c}\text { Sowing Date } \mathrm{X} \text { Row } \\
\text { Spacing }\end{array}$} & NS & NS & NS & $* *$ & NS & $* *$ & $* *$ \\
\hline \multirow{3}{*}{ I } & $20 \mathrm{~cm}$ & 13.013 & 35.552 & 56.500 & 21.333 & 96.598 & 195.027 & 323.681 \\
\hline & $40 \mathrm{~cm}$ & 13.032 & 35.553 & 56.833 & 22.500 & 97.880 & 187.902 & 508.506 \\
\hline & $60 \mathrm{~cm}$ & 13.015 & 35.505 & 56.667 & 24.167 & 96.832 & 109.347 & 307.087 \\
\hline \multirow{3}{*}{ II } & $20 \mathrm{~cm}$ & 8.553 & 29.510 & 52.000 & 27.000 & 95.853 & 322.190 & 434.760 \\
\hline & $40 \mathrm{~cm}$ & 8.520 & 29.505 & 51.333 & 26.333 & 97.100 & 151.840 & 374.299 \\
\hline & $60 \mathrm{~cm}$ & 8.523 & 29.512 & 51.833 & 26.833 & 96.830 & 61.428 & 220.049 \\
\hline \multirow{3}{*}{ III } & $20 \mathrm{~cm}$ & 7.535 & 30.527 & 58.667 & 21.000 & 102.788 & 285.487 & 394.999 \\
\hline & $40 \mathrm{~cm}$ & 7.525 & 30.488 & 59.000 & 19.500 & 104.062 & 170.690 & 377.272 \\
\hline & $60 \mathrm{~cm}$ & 7.547 & 30.340 & 58.833 & 19.833 & 102.635 & 98.527 & 341.910 \\
\hline \multirow{3}{*}{ IV } & $20 \mathrm{~cm}$ & 13.033 & 23.485 & 63.333 & 17.333 & 114.667 & 83.918 & 452.946 \\
\hline & $40 \mathrm{~cm}$ & 13.093 & 23.517 & 63.833 & 15.593 & 114.855 & 43.532 & 219.467 \\
\hline & $60 \mathrm{~cm}$ & 13.068 & 23.502 & 64.667 & 16.267 & 114.562 & 9.802 & 142.508 \\
\hline
\end{tabular}

**: p>0.001; NS: Not significant; PE: Plant emergence period; TG: Transition to generative period; FP: $50 \%$ of flowering period; GF: Grain filling period; GP: Growth period; GY: Grain yield; BY: Biological yield

\section{Transition to generative period (DAS)}

The analysis of the period between the plant emergence and TG revealed that the differences based on the year and sowing date were significant $(\mathrm{p}<0.001)$, and row spacing did not significantly affect the TG. The annual analysis of the study findings demonstrated that the second year TG (26.993 DAS) was shorter when compared to the first year TG (32.506 DAS). The analysis of the reasons for these differences demonstrated that the average temperature was higher in 2018, and the plants received the required temperatures faster and hence, the transition to the generative period was faster in 2018 than 2017. It was suggested that the facts that the average precipitation was lower in 2017 as well as the average temperatures when compared to 2018 and the vegetative period was longer in 2017 were the other factors. 
Sowing date analysis demonstrated that the fastest TG was observed in $4^{\text {th }}$ sowing date with 23.501 DAS and the slowest TG was observed in the $1^{\text {st }}$ sowing date with 35.537 DAS. It was suggested that that increasing temperatures and decreasing precipitation lead to the reduction in the vegetative development period in plants and early TG. In April sowing, it was observed that the plants were transformed to the generative period earlier. This was due to lower temperatures after April 15 and relatively higher precipitation after mid-April when compared to early April.

Table 3c. Effect of different sowing dates and different row spacings on the phenological characteristics of quinoa in 2017 and 2018

\begin{tabular}{|c|c|c|c|c|c|c|c|c|c|}
\hline \multirow{2}{*}{\multicolumn{3}{|c|}{$\begin{array}{l}\text { INTERACTIONS } \\
\text { Year X Sowing Date } \\
\text { X Row Spacing }\end{array}$}} & $\begin{array}{c}\text { PE } \\
(\text { DAS })\end{array}$ & $\begin{array}{c}\text { TG } \\
(\text { DAS })\end{array}$ & $\begin{array}{c}\text { FP } \\
(\text { DAS })\end{array}$ & $\begin{array}{c}\text { GF } \\
(\text { DAS })\end{array}$ & $\begin{array}{c}\mathbf{G} \\
(\mathbf{D A S})\end{array}$ & $\begin{array}{c}\text { GY } \\
\left(\mathrm{kg} \mathrm{da}^{-1}\right)\end{array}$ & $\begin{array}{c}\text { BY } \\
\left(\mathrm{kg} \mathrm{da}^{-1}\right)\end{array}$ \\
\hline & & & NS & NS & NS & $* *$ & NS & $* *$ & $* *$ \\
\hline \multirow{12}{*}{2017} & \multirow{3}{*}{ I } & $20 \mathrm{~cm}$ & 21.037 & 38.003 & 64.000 & 20.000 & 98.060 & 284.627 & 287.960 \\
\hline & & $40 \mathrm{~cm}$ & 21.027 & 38.007 & 64.000 & 20.000 & 100.893 & 271.410 & 676.150 \\
\hline & & $60 \mathrm{~cm}$ & 21.027 & 38.003 & 64.000 & 20.000 & 98.613 & 151.697 & 388.430 \\
\hline & \multirow{3}{*}{ II } & $20 \mathrm{~cm}$ & 9.133 & 32.010 & 58.000 & 26.000 & 103.647 & 524.087 & 507.420 \\
\hline & & $40 \mathrm{~cm}$ & 9.037 & 32.010 & 58.000 & 26.000 & 105.973 & 216.840 & 450.343 \\
\hline & & $60 \mathrm{~cm}$ & 9.047 & 32.010 & 58.000 & 26.000 & 105.713 & 66.657 & 226.633 \\
\hline & \multirow{3}{*}{ III } & $20 \mathrm{~cm}$ & 6.037 & 32.010 & 60.000 & 31.000 & 117.597 & 426.517 & 426.517 \\
\hline & & $40 \mathrm{~cm}$ & 6.023 & 32.010 & 60.000 & 31.000 & 120.150 & 276.733 & 528.467 \\
\hline & & $60 \mathrm{~cm}$ & 6.100 & 32.010 & 60.000 & 31.000 & 117.223 & 147.597 & 447.797 \\
\hline & \multirow{3}{*}{ IV } & $20 \mathrm{~cm}$ & 13.070 & 28.000 & 62.000 & 28.000 & 131.403 & 60.290 & 89.457 \\
\hline & & $40 \mathrm{~cm}$ & 13.120 & 28.000 & 62.000 & 28.000 & 131.707 & 53.253 & 117.173 \\
\hline & & $60 \mathrm{~cm}$ & 13.137 & 28.000 & 62.000 & 28.000 & 131.033 & 58.270 & 70.810 \\
\hline \multirow{12}{*}{2018} & \multirow{3}{*}{ I } & $20 \mathrm{~cm}$ & 4.990 & 33.100 & 49.000 & 22.667 & 95.137 & 105.427 & 359.401 \\
\hline & & $40 \mathrm{~cm}$ & 5.037 & 33.100 & 49.667 & 25.000 & 94.867 & 104.393 & 340.861 \\
\hline & & $60 \mathrm{~cm}$ & 5.003 & 33.007 & 49.333 & 28.333 & 95.050 & 66.997 & 225.743 \\
\hline & \multirow{3}{*}{ II } & $20 \mathrm{~cm}$ & 7.973 & 27.010 & 46.000 & 28.000 & 88.060 & 120.293 & 362.100 \\
\hline & & $40 \mathrm{~cm}$ & 8.003 & 27.000 & 44.667 & 26.667 & 88.227 & 86.840 & 298.255 \\
\hline & & $60 \mathrm{~cm}$ & 8.000 & 27.013 & 45.667 & 27.667 & 87.947 & 56.200 & 213.465 \\
\hline & \multirow{3}{*}{ III } & $20 \mathrm{~cm}$ & 9.033 & 29.043 & 57.333 & 11.000 & 87.980 & 144.457 & 363.481 \\
\hline & & $40 \mathrm{~cm}$ & 9.027 & 28.967 & 58.000 & 8.000 & 87.973 & 64.647 & 226.077 \\
\hline & & $60 \mathrm{~cm}$ & 8.993 & 28.670 & 57.667 & 8.667 & 88.047 & 49.457 & 236.023 \\
\hline & \multirow{3}{*}{ IV } & $20 \mathrm{~cm}$ & 12.997 & 18.970 & 64.667 & 6.667 & 97.930 & 107.547 & 816.435 \\
\hline & & $40 \mathrm{~cm}$ & 13.067 & 19.033 & 65.667 & 3.187 & 98.003 & 33.810 & 321.761 \\
\hline & & $60 \mathrm{~cm}$ & 13.000 & 19.003 & 67.333 & 4.533 & 98.090 & 13.777 & 214.205 \\
\hline \multirow{2}{*}{\multicolumn{3}{|c|}{$\begin{array}{l}\text { Average } \\
\text { CV \% }\end{array}$}} & 10.538 & 29.75 & 57.792 & 21.474 & 102.889 & 143.307 & 341.457 \\
\hline & & & 1.177 & 0.332 & 1.908 & 2.671 & 0.775 & 3.691 & 5.499 \\
\hline
\end{tabular}

**: p>0.001; NS: Not significant; PE: Plant emergence period; TG: Transition to generative period; FP: $50 \%$ of flowering period; GF: Grain filling period; GP: Growth period; GY: Grain yield; BY: Biological yield

It was determined that the impact of the interaction between years' $\mathrm{x}$ sowing date on TG was statistically significant, while the differences between other interactions were not statistically significant. The analysis of the data on year $\mathrm{x}$ sowing date interaction demonstrated that the shortest TG was observed with the $4^{\text {th }}$ sowing date in both years (28.000 and 19.002 DAS). It was observed that the longest TG was obtained with the $1^{\text {st }}$ sowing date (38.004 and 33.069 DAS) in both years. The fact that the temperatures were 
above the optimum temperature required for plant development shortened the transition to the generative period. Accordingly, Bertero et al. (2004) reported that the plant growth and development stages could differ based on the time that the plant could receive the total heat it requires.

\section{Days to $50 \%$ of flowering period (DAS)}

The analysis of the data on FP, which is one of the important stages in plant development, demonstrated that differences between FP were significant $(p<0.001)$ based on the year and sowing date parameters; however, the effect of row spacing on FP was not significant. The annual analysis demonstrated that the earliest $50 \%$ of flowering (54.583 DAS) was observed in 2018, while it was observed a little later (61.000 DAS) in 2017.

The analysis of the effect of sowing date on FP demonstrated that FP varied between $51.722\left(2^{\text {nd }}\right.$ sowing $)$ and $63.944\left(4^{\text {th }}\right.$ sowing $)$ DAS. The analysis of the FP based on the sowing date demonstrated that $50 \%$ of flowering took longer in May sowing due to the transition of the plant to the generative period coincided with long DAS, since quinoa is a short-day plant. Considering that the temperatures were relatively high in the first half of April when compared to March, and precipitation decreased gradually after the second half of April, and the DAS were extended from March to May at the study site.

The analysis of the interactions between the year and the applications demonstrated that the interaction between the year $\mathrm{x}$ sowing date was significant while, the other interactions were statistically insignificant. FP varied between 45.444 and 65.889 DAS for the year $\mathrm{x}$ sowing date interaction. Based on the study years, the earliest $50 \%$ of flowering was observed in the $2^{\text {nd }}$ sowing in 2017, while the latest $50 \%$ of flowering was observed in the $1^{\text {st }}$ sowing with 64 DAS. The earliest $50 \%$ of flowering was observed in the $2^{\text {nd }}$ sowing in the second year with 45.444 DAS and the latest $50 \%$ of flowering was observed in the $4^{\text {th }}$ sowing date with 65.889 DAS.

Belmonte et al. (2018) reported that FP varied between 53.8 and 57.7 DAS in quinoa genotypes grown in Parana, Brazil ecosystem. In that study, the findings of which were generally consistent with the present study results, Belmonte et al. (2018) utilized 16 genotypes, while a single variety was used in the current study. However, the range of the findings obtained with a single variety (54.6-61.0 DAS) was wider. The high difference in the findings was due to the differences in the annual climate data during the experiments.

\section{Grain filling period (DAS)}

The period between the $50 \%$ of flowering and completion of grain filling in at least $50 \%$ of the plants in the lot is an important period that affects the crop yield and quality. Thus, the analysis of the differences in this period is a significant issue. It was observed that the analyzed factors of the year, sowing date and row spacing significantly affected the GF in the study $(\mathrm{p}<0.001)$. Comparison of the grain filling time based on the study years demonstrated that the period was longer in the first year (26.250 DAS) when compared to the second year (16.699 DAS). The analysis of average annual temperatures during the experiment generally demonstrated that the average temperature was $2{ }^{\circ} \mathrm{C}$ higher in 2018 when compared to the previous year; however, the analysis of annual temperatures demonstrated that the lowest and highest temperatures fluctuated significantly, affecting the GF. 
Comparison of the grain filling time based on the sowing date, the process varied between 16.399 and 26.722 DAS and the longest GF was observed in the $2^{\text {nd }}$ sowing date and the shortest was observed in the $4^{\text {th }}$ sowing date. The analysis of GF based on the sowing date in the present study demonstrated that the longest GF was due to the fact that the generative period coincided with longer days in the first half of April. It was observed that this period was longer when compared to March sowing. Consistent with the findings reported by Christiansen et al. (2010), this suggested that GF gets longer as the days get longer, and in later sowing dates, the period gradually shortens due to the longer daylight, and increasing temperatures counteract the impact of the longer days, maturing the plants faster.

The analysis of this factor based on row spacing demonstrated that $20 \mathrm{~cm}$ row spacing (21.667 DAS) and $60 \mathrm{~cm}$ row spacing (21.775 DAS) exhibited similar periods and there was no statistically difference; however, a shorter period was observed with the $40 \mathrm{~cm}$ row spacing when compared to the other two row spacing distances (20.982 DAS) and there was a significant difference between this and the others row spacing distances. While the impact of row spacing on the plant grain filling process was also significant, it was determined that shoots did not develop in dense sowing ( $20 \mathrm{~cm}$ spacing), the plant completed development on the main stem and was not exposed to the sun sufficiently, while in sparse sowing (60 $\mathrm{cm}$ spacing), higher number of shoots developed and maturation of the shoot clusters extended the period, and the fact that the periods were shorter in $40 \mathrm{~cm}$ row spacing demonstrated that the ideal row spacing was $40 \mathrm{~cm}$ for GF with the applied row spacing distances.

It was determined that the effects of the interactions between year $\mathrm{x}$ sowing date, year $\mathrm{x}$ row spacing, sowing date $\mathrm{x}$ row spacing, and year $\mathrm{x}$ sowing date $\mathrm{x}$ row spacing on quinoa plant GF were statistically significant in the study $(\mathrm{p}<0.001)$. It was found that the GF varied between $4.796\left(2018 ; 4^{\text {th }}\right.$ sowing $)$ and $31.000\left(2017 ; 3^{\text {rd }}\right.$ sowing $)$ DAS based on the year $x$ sowing date interaction, the same period varied between 15.713 (2018; $40 \mathrm{~cm})$ and $26.250(2017 ; 20,40$ and $60 \mathrm{~cm})$ DAS based on the year x row spacing interaction, it varied between $15.593\left(4^{\text {th }} ; 40 \mathrm{~cm}\right)$ and $27.000\left(2^{\text {nd }} ; 20 \mathrm{~cm}\right)$ DAS based on sowing date $\mathrm{x}$ row spacing interaction, and the GF varied between $3.187\left(2018 ; 4^{\text {th }}\right.$; $40 \mathrm{~cm})$ and $31.000\left(2017 ; 3^{\text {rd }} ; 20,40\right.$ and $\left.60 \mathrm{~cm}\right)$ DAS based on the year $\mathrm{x}$ sowing date $\mathrm{x}$ row spacing interaction.

\section{Growing period (DAS)}

The analysis of the effects of year, sowing date and row spacing on the quinoa plant GP demonstrated that all three factors led to differences in GP and the differences were statistically significant $(\mathrm{p}<0.001)$. GP differed based on the year, and it was observed that it was longer in the first year (113.501 DAS) when compared to the second year (92.276 DAS). It was observed that the difference was due to higher temperature fluctuations in 2018 when compared to 2017, although the average temperature was higher in 2018. The fact that the average temperature was higher in 2018 when compared to 2017 led to shorter plant GP. Also, the fact that the precipitation was lower in 2018, unlike the temperatures, allowed the plants to mature earlier. The decrease in relative humidity with precipitation shortened the maturation period.

The differences based on sowing date were between $97.103\left(1^{\text {st }}\right)$ and $114.694\left(2^{\text {nd }}\right)$ DAS and it was observed that the GP increased as the sowing date was delayed. This could be associated with the facts that the growth of quinoa, a short-day plant, coincided with shorter days in early April sowing dates when compared to later sowing dates, the 
temperatures were at favorable degrees for the germination and development of quinoa and this season was rainier, leading to the minimum GP. Although the increase in temperatures in the following periods had a positive effect on the GP, prolongation of days, resulting higher radiation levels and low relative moisture due to lower precipitation extended the GP. It was observed that differences based on row spacing varied between $102.477(20 \mathrm{~cm})$ and $103.474(40 \mathrm{~cm})$ DAS; however, the differences in GP based on $20 \mathrm{~cm}$ row spacing and $60 \mathrm{~cm}$ row spacing were not statistically significant.

The analysis of the interactions between the factors that affected the quinoa plant GP demonstrated that the differences between year $\mathrm{x}$ sowing date and year $\mathrm{x}$ row spacing interactions were statistically significant $(\mathrm{p}<0.001)$. The individual analysis of the differences demonstrated that the growth time varied between $88.000\left(2018 ; 3^{\text {rd }}\right)$ and $131.381\left(2017 ; 4^{\text {th }}\right)$ DAS based on the year $\mathrm{x}$ sowing date interaction and between 92.268 $(2018 ; 40 \mathrm{~cm})$ and $114.681(2017 ; 40 \mathrm{~cm})$ DAS based on the interaction between years' $\mathrm{x}$ row spacing.

In the present study, it was observed that the GP varied between 87.68 and 133.06 DAS and these figures were significantly consistent with previous study findings. In other studies, it was reported that the total GP varied between 108 and 181 DAS (Jacobsen, 2003) in Denmark and 130 and 140 DAS (Szilagyi and Jørnsgård, 2014) in Romania. The finding that these variations were due to the variety (Jacobsen, 2003; Szilagyi and Jørnsgård, 2014), photoperiod and temperatures, sowing date, soil structure and climate conditions (Hirich et al., 2012) confirmed the present study findings.

\section{Grain yield ( $\mathrm{kg} \mathrm{da^{-1 } )}$}

The analysis of the GY data demonstrated that the year, sowing date and row spacing factors led to significant ( $p<0.001$ ) differences in GY. While the GY was $207.128 \mathrm{~kg} \mathrm{da}^{-1}$ in 2017, the same yield was only $79.487 \mathrm{~kg} \mathrm{da}^{-1}$ in 2018 . The analysis of the caused for this decline suggested that the soil properties were better in the first year experiment and contained more salt and organic matter when compared to the soil where the second year trial was conducted, promoting plant development and grain formation, and the low precipitation regime and higher temperatures experienced in the second year reduced the grain formation and prevented the grains to reach maturity. On the other hand, the sudden and heavy rainfall in June produced floods, destroying several plants. The decrease in the plant count and heavy down pours led to the falling of the grains and hence low GY.

The analysis based on the sowing date demonstrated that the GY varied between $45.751\left(4^{\text {th }}\right)$ and $184.901\left(3^{\text {rd }}\right) \mathrm{kg} \mathrm{da}^{-1}$. It was suggested that ideal air and soil temperatures following the sowing and precipitation sufficient for grain formation and maturing led to the highest GY. On the other hand, the coincidence of the generative period with longer days in May sowing and the negative impact of high temperatures and low relative humidity on pollen viability led to low GY (Martinez et al., 2009; Hirich et al., 2014). Furthermore, the sudden increase in temperatures accelerated weed growth and negatively affected quinoa plants that have low competitiveness during first emergence and seedling periods and led to serious decreases in plant count. This indirectly led to low GY.

It was determined that row spacing led to a change in yield between $69.776(60 \mathrm{~cm})$ and $221.655(20 \mathrm{~cm}) \mathrm{kg} \mathrm{da}^{-1}$. This suggested that the decrease in the number of plants per square meter led to a decrease in GY (Geren et al., 2015).

In addition to factors such as year, sowing date and row spacing, the interactions between these factors; year $\mathrm{x}$ sowing date, year $\mathrm{x}$ row spacing, sowing date $\mathrm{x}$ row spacing 
and year $\mathrm{x}$ sowing date $\mathrm{x}$ row spacing interactions also led to differences in GY. It was found that the differences due to all interactions were statistically significant $(\mathrm{p}<0.001)$. GY values varied between $39.790\left(2017 ; 4^{\text {th }}\right)$ and $283.616\left(2017 ;\right.$ III) $\mathrm{kg} \mathrm{da}^{-1}$ based on year x sowing date, between $46.608(2018 ; 60 \mathrm{~cm})$ and $323.880(2017 ; 20 \mathrm{~cm}) \mathrm{kg} \mathrm{da}^{-1}$ based on year x row spacing interaction, between $9.802\left(4^{\text {th }} ; 60 \mathrm{~cm}\right)$ and $322.190\left(2^{\text {nd }}\right.$; $20 \mathrm{~cm}) \mathrm{kg} \mathrm{da}^{-1}$ based on sowing date $\mathrm{x}$ row spacing interaction, and between 13.777 $\left(2018 ; 4^{\text {th }} ; 60 \mathrm{~cm}\right)$ and $524.087\left(2017 ; 2^{\text {nd }} ; 20 \mathrm{~cm}\right) \mathrm{kg} \mathrm{da}^{-1}$ based on year $\mathrm{x}$ sowing date $\mathrm{x}$ row spacing interaction.

It was determined that the GY values obtained in the study were generally consistent with the findings obtained in previous studies on quinoa. Gesisnski (2008) reported that GY varied between 25 and $500 \mathrm{~kg} \mathrm{da}^{-1}$ in various genotypes, Bhargava et al. (2007) reported that different genotypes led to GY between 32 and $983 \mathrm{~kg} \mathrm{da}^{-1}$ with different row spacing applications and Szilagyi and Jørnsgård (2014), on the other hand, reported GY values between 170 and $296 \mathrm{~kg} \mathrm{da}^{-1}$ in Romania using various genotypes.

\section{Biological yield $\left(\mathrm{kg} \mathrm{da}^{-1}\right)$}

The analyses conducted in the study demonstrated that the plant yield varied based on the differences between years, sowing dates and row spacing and these differences were statistically significant $(\mathrm{p}<0.001)$. Annual plant yield varied between 331.484 and $351.430 \mathrm{~kg} \mathrm{da}^{-1}$ and plant yield was higher in the first year when compared to the second year. It was suggested that the difference was due to soil and climate properties during the 2018 trial. Because, a flood that could only be seen twice in a century occurred in June 2018 and broke the small plant branches. While regular rains have a positive contribution to the yield (Kir and Temel, 2016), unexpected rains have negative effects.

The analysis of the plant yield based on sowing date revealed that the yield varied between $271.640\left(4^{\text {th }}\right)-379.758\left(1^{\text {st }}\right) \mathrm{kg} \mathrm{da}^{-1}$. During the first sowing, the air and soil temperatures were lower when compared to the other sowing dates. However, the precipitation was quite high, and the plants met their water requirements during the vegetation period. While the decrease in precipitation during the May sowing led to a decrease in relative humidity, the increase in the temperatures also led to the receipt of required heat by the plants at an earlier date and transition of the plants to the generative period quickly. This results in a decrease in green plant sections and consequently reduces BY (Kaya et al., 2000). On the other hand, Geren et al. (2015) as they stated in their work, higher temperatures during the $4^{\text {th }}$ sowing led to an increase in weed population in the cultivation fields and preventing shoot production by the quinoa seedlings and decreasing weight per unit area. Following the first sowing, the highest BY was obtained in $3^{\text {rd }}$ sowing. In this period, although precipitation decreased when compared to the first sowing, the higher air temperatures increased BY by promoting the vegetative development of the plant (Sajjad et al., 2014).

In various row spacing applications, it was observed that the plant yield varied between $252.888(60 \mathrm{~cm})$ and $401.596(20 \mathrm{~cm}) \mathrm{kg} \mathrm{da}^{-1}$. The higher plant count per decare in sowing parties with low row spacing led to higher BY in these lots.

In the experiments, it was determined that interactions between the year, sowing date and row spacing parameters that affected plant yield led to significant variations in plant yield as well ( $\mathrm{p}<0.001)$. It was determined that plant yield varied between 92.480 (2017; $\left.4^{\text {th }}\right)$ and $467.593\left(2017 ; 3^{\text {rd }}\right) \mathrm{kg} \mathrm{da}^{-1}$ based on year $\mathrm{x}$ sowing date interaction, and between $222.359(2018 ; 60 \mathrm{~cm})-475.354(2018 ; 20 \mathrm{~cm}) \mathrm{kg} \mathrm{da}^{-1}$; based on year $\mathrm{x}$ row spacing interaction, between $142.508\left(4^{\text {th }} ; 60 \mathrm{~cm}\right)$ and $508.506\left(1^{\text {st }} ; 40 \mathrm{~cm}\right) \mathrm{kg} \mathrm{da}^{-1}$ based on the 
sowing date $\mathrm{x}$ row spacing interaction, and between $70.810\left(2017 ; 4^{\text {th }} ; 60 \mathrm{~cm}\right)$ and $816.435\left(2018 ; 4^{\text {th }} ; 20 \mathrm{~cm}\right) \mathrm{kg} \mathrm{da}^{-1}$ based on the year $\mathrm{x}$ sowing date $\mathrm{x}$ row spacing interaction.

It was observed that the present study BY findings were consistent with previous study findings. Shams (2012) reported BY figures between 232.2 and $278.7 \mathrm{~kg} \mathrm{da}^{1-}$, Sajjad et al. (2014) reported BY figures between 619.0 and $763.4 \mathrm{~kg} \mathrm{da}^{1-}$, and Kir and Temel (2016) reported BY figures between 550.8 and $780.6 \mathrm{~kg} \mathrm{da}^{1-}$.

\section{Conclusion}

In the study, where different sowing date and plant spacing applications were investigated in Q-52 quinoa variety cultivation in Kahramanmaraş province, where Mediterranean climate prevails, it was determined that it was important to ensure the first emergence of the plant, the temperatures above the seasonal norms during the emergence led to damages in seedlings, and weed competition was weak during the seedling period. It was observed that weed competition was good after the shooting period. It was determined that quinoa plant could be sown in March and April in the Mediterranean coast, and the desired yield could not be obtained in the following months. Considering $\mathrm{GY}$ and BY at various row spacing applications, it was concluded that $20 \mathrm{~cm}$ row spacing was adequate.

\section{REFERENCES}

[1] Anonim (2019): T.C. Ministry of forestry and water affairs, general directorate of meteorology, Kahramanmaraş.

[2] Belmonte, C., de Vasconcelos, E. S., Tsutsumi, C. Y., Lorenzetti, E., Hendges, C., Coppo, J. C., Martinez, A. S., Pan, R., Brito, T. S., Inagaki, A. M. (2018): Agronomic and productivity performance for quinoa genotypes in an agroecological and conventional production system. - American Journal of Plant Sciences 9(04): 880.

https://doi.org/10.4236/ajps.2018.94067.

[3] Bertero, H. D., de la Vega, A. J., Correa, G., Jacobsen, S. E., Mujica, A. (2004): Genotype and genotype-by-environment interaction effects for grain yield and grain size of quinoa (Chenopodium quinoa Willd.) as revealed by pattern analysis of international multienvironment trials. - Field Crops Research 89: 299-318. https://doi.org/10.1016/j.fcr.2004.02.006.

[4] Bhargava, A., Shukla, S., Rajan, S., Ohri, D. (2007): Genetic diversity for morphological and quality traits in quinoa (Chenopodium quinoa Willd.) germplasm. - Genetic Resources and Crop Evolution 54(1): 167-173. https://doi.org/10.1007/s10722-005-3011-0.

[5] Christiansen, J., Jacobsen, S. E., Jørgensen, S. E. (2010): Photoperiodic effect on flowering and seed development in quinoa (Chenopodium quinoa Willd.). - Acta Agriculturae Scandinavica Section B Soil and Plant Science 60: 539-544. https://doi.org/10.1080/09064710903295184.

[6] Etchevers, J., Avila, P. (1979): Agronomic behavior of quinoa cultivation (Chenopodium quinoa wild) in Chile. - Simiente 36(2).

[7] Geren, H., Kavut, Y. T., Demiroğlu Topçu, G., Ekren, S., İştipliler, D. (2014): Effects of different sowing dates on the grain yield and some yield components of quinoa (Chenopodium quinoa Willd.) grown under mediterranean climatic conditions. - Journal of Agriculture Faculty of Ege University 51(3): 297-305.

https://doi.org/10.20289/euzfd.46525. 
[8] Geren, H., Kavut, Y. T., Altınbaş, M. (2015): Effect of different row spacings on the grain yield and some yield characteristics of quinoa (Chenopodium quinoa Willd.) under Bornova ecological conditions. - Journal of Agriculture Faculty of Ege University 52(1): 69-78. https://doi.org/10.20289/euzfd.64719.

[9] Gesinski, K. (2008): Evaluation of the development and yielding potential of Chenopodium quinoa Willd. under the climatic conditions of Europe, Part One: accomodation of Chenopodium quinoa (Willd.) to different conditions. - Acta Agrobotanica 61(1): 179-184.

[10] Hirich, A., Allah, R. C., Jacobsen, S. E., El Youssfi, L., El Homaria, H. (2012): Using deficit irrigation with treated wastewater in the production of quinoa (Chenopodium quinoa Willd.) in Morocco. - Revista Científica UDO Agrícola 12(3): 570-583.

[11] Hirich, A., Choukr-Allah, R., Jacobsen, S. E. (2014): Quinoa in Morocco-effect of sowing dates on development and yield. - Journal of Agronomy and Crop Science 200(5): 371377. https://doi.org/10.1111/jac.12071.

[12] Jacobsen, S. E. (2003): The worldwide potential for quinoa (Chenopodium quinoa Willd.). - Food Rev. Int. 19(1-2): 167-177. https://doi.org/10.1081/FRI-120018883.

[13] Kaya, N., Y1lmaz, G., Telci, İ. (2000): Agronomic and technological properties of coriander (Coriandrum sativum L.) populations planted on different dates. - Turk J Agric For 24: 355-364.

[14] Kir, A. E., Temel, S. (2016): Determination of seed yield and some agronomical characteristics of different quinoa (Chenopodium quinoa Willd.) variety and populations under dry conditions of Igdir plain. - Iğdır Univ. J. Inst. Sci. \& Tech. 6(4): 145-154. https://doi.org/10.21597/jist.2016624166.

[15] Martínez, E. A., Veas, E., Jorquera, C., San Martín, R., Jara, P. (2009): Re-introduction of quinoa into arid Chile: cultivation of two lowland races under extremely low irrigation. J. Agron. Crop Sci. 195: 1-10. https://doi.org/10.1111/j.1439-037X.2008.00332.x.

[16] Mujica, Á., Jacobsen, S. (2006): La quinua (Chenopodium quinoa Willd) y sus parientes silvestres. - Botánica Económica de los Andes Centrales, pp. 449-457.

[17] Sajjad, A., Ehsanullah, H. M., Anjum, S. A., Tanveer, M., Rehman, A. (2014): Growth and development of Chenopodium quinoa genotypes at different sowing dates. - J. Agricultural Research 52(4): 535-546.

[18] Shams, A. S. (2012): Response of quinoa to nitrogen fertilizer rates under sandy soil conditions. - Proc. 13 ${ }^{\text {th }}$ international Conf. Agron., Fac. of Agic., Benha Univ., Egypt, 910 September 2012, pp. 195-205.

[19] Szilagyi, L., Jørnsgård, B. (2014): Preliminary agronomic evaluation of Chenopodium quinoa Willd. under climatic conditions of Romania. - Scientific Papers, Series A. Agronomy, Vol. LVII.

[20] Tan, M., Temel, S. (2017): Studies on the adaptation of quinoa (Chenopodium quinoa Willd.) to eastern anatolia region of Turkey. - AGROFOR International Journal 2(2): 3339.

[21] Zurita-Silva, A., Fuentes, F., Zamora, P., Jacobsen, S. E., Schwember, A. R. (2014): Breeding quinoa (Chenopodium quinoa Willd.): potential and perspectives. - Mol. Breed. 34: 13-30. https://doi.org/10.1007/s11032-014-0023-5. 